DOI: $10.17951 / \mathrm{m} \cdot 2019.4 .53-67$

\begin{tabular}{lcr}
\hline & ANNALES & \\
& & \\
UNIVERSITATIS MARIAE CURIE-SKLODOWSKA & \\
LUBLIN - POLONIA & \\
VOL. IV & SECTIO M & 2019 \\
\hline
\end{tabular}

Justyna Miecznikowska

University of Warsaw

j.miecznikowska@uw.edu.pl

ORCID ID: http://orcid.org/0000-0003-0971-6884

\title{
The 2019 Austrian government crisis - political consequences of the Ibiza affair
}

\section{Introduction}

This article considers the political consequences of the largest government crisis in the history of the Second Republic of Austria. This ensued after the media revealed in May 2019 the knowingly corrupt activity of the ruling Freedom Party of Austria (German: Freiheitliche Partei Österreichs - FPÖ). Filmed in July 2017 on Ibiza, a candid video recorded a meeting of the chairman of the Freedom Party, Heinz Christian Strache, and the chairman of the FPÖ's parliamentary faction, Johann Gudenus, with a woman posing as a relative of a Russian oligarch Igor Makarov. During the talks, H. Ch. Strache declared that, if the Russian businessman bought the influential Austrian tabloid 'Kronen Zeitung' and then used it to support the FPÖ in the upcoming parliamentary elections, then upon the party's victory, he would gain access to public contracts.

The video sting scandal, labelled Ibiza-gate, has shaken Austria, causing not just an overhaul of the Sebastian Kurz's cabinet, but a full collapse of the coalition between the Austrian People's Party (German: Österreichische Volkspartei - ÖVP) and the Freedom Party of Austria. The 18-month cooperation of both parties at the federal level had been based on shared views on the immigration crisis, criticism of liberal immigration policy and calls for a root -and-branch reform of Austria's fiscal and social policies. 
Having left the coalition, the FPÖ supported the no-confidence vote against the Sebastian Kurz's cabinet. In the wake of these events, President Alexander van der Bellen called a snap parliamentary election and appointed Brigitte Bierlein to lead a technocratic interim government.

At the centre of my deliberations in this article are the following research questions: 1) What are the political consequences of the government crisis precipitated by the publication of video footage implicating the FPÖ politicians? 2) What was the public perception of the video sting scandal? 3) How did revealing the scandal affect the results of the snap election to the Austrian National Council?

In this article, a hypothesis is put forward that the scandal has strengthened the Christian Democrats' position on the Austrian political scene, despite opposition criticism that ÖVP, which had agreed to cooperate with the extreme right, is co-responsible for the political crisis.

The article is comprised of three parts: firstly, it presents an account of the events that brought about Austria's governmental crisis and snap parliamentary elections. Next, it refers to opinion polls exploring how the public views political parties, corruption among politicians, as well as the functioning of democracy in Austria. The third part shows the results of parliamentary elections, compares support received by the individual parties in 2017 and 2019 elections, and analyses shifts in voting preferences.

The article incorporates an analysis of the relevance of the content of parliamentary letters and the debate held during the special session on 27 May 2019. It also uses the opinion polls commissioned by the ORF public broadcaster and carried out by the SORA/ISA Institute (Institut für Strategieanalyse und Institute for Social Research and Analysis), as well as surveys carried out by the INTEGRAL Institute on the Day of Democracy (15 September 2019). Based on the official results published by the Ministry of the Interior of Austria and on SORA/ISA polls, the article delineates a shift of voters among political formations and provides electoral profiles of individual groupings in terms of the assessment of the political situation in Austria and motives for voters' decisions.

\section{The fall of the Sebastian Kurz cabinet}

After the weekly news magazine 'Der Spiegel' and the daily 'Süddeutsche Zeitung' had revealed the compromising video on 17 May 2019, the ViceChancellor, Heinz Christian Strache stepped down and resigned as chairman 
of the FPÖ, which he had headed since $2005^{1}$. In a social media statement, Strache admitted that his behaviour had been 'stupid and irresponsible', for which he apologised to the electorate. At the same time, Strache explained that the 7-minute illegal recording was a compilation of many hours of video footage, thus many statements had been taken out of context. The politician assured that he did not continue the talks which had been initiated in Ibiza two years before and that none of the ideas brought up at the meeting had been put into action. According to Strache, the video was meant not so much to discredit the FPÖ or him personally as to destabilise the situation in the country, and therefore, constituted an attack on a democratic and sovereign federal government of Austria.

After H. Ch. Strache had stepped down, the Freedom Party of Austria announced it was willing to continue its coalition with the Christian Democrats. For Chancellor Sebastian Kurz, a necessary condition for cooperation between both parties was the resignation of Herbert Kickl - Interior Minister, who was FPÖ secretary-general at the time the Ibiza video was made. This cabinet reshuffle was supposed to facilitate an unbiased investigation into cash flows to FPÖ accounts. For the Freedom Party, the demands to sack Kickl served as a pretext to scrap the coalition with the Christian Democrats. In the face of the government crisis, Sebastian Kurz asked the president to appoint four non-partisan experts as ministers to replace the resigning FPÖ politicians and to hold early National Council elections. Alexander van der Bellen announced that the snap parliamentary election would be held in September 2019.

The video sting scandal erupted just a week before the European Parliament elections, which prompted speculation on the part of the Freedom Party that revealing the Ibiza video after two years was a political attack and 'a honey trap, directed by intelligence agencies' which was supposed to discredit the FPÖ in the public eye. Having analysed the results of the EP elections held in Austria on 26 May 2019, however, one finds no proof that revealing the corruption video and the ensuing scandal had much of an influence on voters' decisions. ${ }^{2}$ In the election, the Christian Democrats won a clear election victory with 7 seats $(2$ more than in 2014) and $34.6 \%$ of votes, having improved their result by more than 7 percentage points compared to the previous elections. Moreover, the Social Democratic Party of Austria (German: Sozialdemokratische Partei Österreichs

1 The helm of the Freedom Party of Austria was taken over by Norbert Hofer, vice-chairman of the FPÖ and transport minister in Kurz's cabinet, who in 2016 was the Freedom Party's presidential candidate.

2 Ergebnisse der Europawahl Österreich 2019, https://europawahlergebnis.eu/nationaleergebnisse/osterreich/2019-2024/, retrieved 14 October 2019 
- SPÖ) received nearly 24\%, which secured them 5 seats in the European Parliament. The Freedom Party of Austria, however, despite a 2 percentage point drop in support and loss of one seat in the EP (compared to the 2014 elections), still came in as the third largest party in Austria. Looking at the FPÖ's good result, one may get an impression that the party's traditional electorate was sceptical about media reports and accepted $\mathrm{H}$. Ch. Strache's explanation that the video scandal was media entrapment, a conspiracy, intelligence agencies' operation and an attack on Austrian democracy.

According to polling undertaken by the SORA/ISA Institute, three quarters of those surveyed denied that the government crisis played a significant part in the elections, only $8 \%$ of respondents said that the scandal provided them with motivation for political participation, $7 \%$ admitted having voted for a different party than they had originally intended, while $9 \%$, stated that because of the video scandal, they did not vote in the elections ${ }^{3}$. The Ibiza video was, therefore, without decisive impact for any of voting groups, including those regularly voting FPÖ. The main electoral motivation for Social Democrats and Greens' voters was support for their European programmes, the credibility of the parties, as well as thwarting the right-wing groups from winning in the EU. For Christian Democrats' voters, the key points were the programme issues, proposed EP candidates and support granted to Sebastian Kurz. As their main motivation, FPÖ voters pointed to the party's past work for the country. For NEOS voters, the key issues were the party programme, candidates for MEPs and credibility of the party ${ }^{4}$

Still, a survey carried out by Peter Hajek, a political scientist and public opinion pollster, confirms that $28 \%$ of the respondents agree that the video scandal influenced (ranging from 'very much', through 'rather', to 'slightly') their decisions in the EP elections. The scandal had the most effect on NEOS voters (41\%) and the least effect on Greens' voters (20\%). Among the five main motives for SPÖ voters, objection to the dominance of right-wing parties, critical assessment of the government while Ibiza-gate (chosen by $16 \%$ of all those polled) ranked third. Second place among key motives for FPÖ voters was their support for the right and a deeply rooted belief that the video sting scandal had been orchestrated to discredit their party $(19 \%)^{5}$.

3 Wahl zum Europäischen Parlament 2019 in Österreich Wahlanalyse . SORA/ISA Institut für Strategieanalyse im Auftrag des ORF, s. 5. https://www.sora.at/fileadmin/downloads/wahlen/2019_EUW_Wahlanalyse.pdf, retrieved 14 October 2019. Ibidem, s. 9.

5 P. Hajek, Die Analyse zur Europa-Wahl 2019: Wer wen warum wählte, https://politikmagazin.at/europa-wahl-2019-wer-wen-warum-waehlte/?cookie-state-change=1572255209253, retrieved 14 October 2019. 
A day after the EP elections, clearly won by Sebastian Kurz's Christian Democrats, at a special session of the National Council, a debate was held in connection with an urgent question (German: dringliche Anfrage) submitted to the Chancellor by the parliamentary faction head Jörg Leichtfried. ${ }^{6}$ In it, the opposition accused the head of the government of making decisions in times of political crisis alone, without consulting the opposition. ${ }^{7}$ J. Leichtfried emphasised that he had no trust in Sebastian Kurz as head of the government, as he was the one fully responsible for the fiasco of the 'dangerous political experiment' - making a federal coalition with the far-right FPÖ. Sharing power with the populists, according to the SPÖ parliamentary faction head, supposedly had a negative impact on democracy and freedom of the press, damaged Austria's image in the international arena and contributed to a deep polarisation of society. The Social Democrats also reproached Kurz for his willingness to continue cooperation with the coalition partner even after the compromising Ibiza video had been made public - as long as the FPÖ agreed to personal changes. According to the SPÖ, this proves that the main motivation for Kurz is to stay in power at whatever cost. The Chancellor rejected criticism by pointing out that he had consulted many parties in person and over the phone and the no-confidence motion tabled by the SPÖ was a tactical move on the part of that opposition party.

On 27 May 2019, at the National Council session, the opposition party JETZT - Peter Pilz List (JETZT - Liste Pilz) proposed a no-confidence motion against the Chancellor. ${ }^{8}$ The party demanded, along with Sebastian Kurz's resignation, the appointment of a technocratic government which would bring back stability and voter confidence in the political system until a new government was formed after the snap parliamentary elections. In the same session, the Social Democrats led by Pamela Rendi Wagner put forward a motion for snap elec-

${ }^{6}$ Dringliche Anfrage gem. $\$ 93$ Abs. 2 GOG der Abgeordneten Mag. Jörg Leichtfried,

Genossinnen und Genossen an den Bundeskanzler betreffend Scheitern der Bundesregierung Kurz, Eingelangt am 27.05.2019, https://www.parlament.gv.at/PAKT/VHG/XXVI/J/J_03619/ fname_754320.pdf, retrieved 14 October 2019.

7 Parlamentskorrespondenz Nr. 588 vom 27.05.2019, Nationalrat spricht gesamter Bundesregierung das Misstrauen aus, https://www.parlament.gv.at/PAKT/AKT/SCHLTHEM/ SCHLAG/J2019/110Misstrauensantrag.shtml, retrieved 14 October 2019.

8 Entschliessungsantrag der Abgeordneten Dr. Alfred Noll, Dr. Peter Pilz, Kolleginnen und Kollegen

betreffend Versagen des Vertrauens gegenüber dem Bundeskanzler eingebracht im Zuge einer Debatte über die Dringliche Anfrage in der 78. Sitzung des Nationalrates, XXVI. GP, am 27. Mai 2019. https://www.parlament.gv.at/PAKT/VHG/XXVI/UEA/UEA_00237/imfname_754666.pdf, retrieved 14 October 2019. 
tions for the National Council in September $2019^{9}$. Justifying their motion, the Social Democrats ruled out the possibility of the Christian Democratic cabinet led by Kurz surviving until the elections (even with some non-partisan experts) due to loss of public trust in government. Herbert Kickl also joined criticism of Chancellor's actions and expressed his disappointment with the steps taken by his former coalition partner, interpreting the cabinet reshuffle as the ÖVP's grab for total power ${ }^{10}$

During the vote, the no-confidence motion against the government as a whole was backed by the National Council members from the SPÖ and Jetzt, as well as from the FPÖ (111 out of 186 votes). The motion was not backed by the Liberals from the NEOS, who supported Chancellor Kurz. For the first time in the history of the Second Republic of Austria, the parliament voted no-confidence to a cabinet of ministers - causing its fall. Furthermore, never before had a former coalition partner joined a motion submitted by the opposition, thus contributing to the demise of a cabinet it was a part of.

On 28 May 2019, President Van der Bellen relieved the Sebastian Kurz's cabinet of its duties after less than 18 months in power. At first, the President appointed Hartwig Löger of the ÖVP as head of the caretaker government, but two days later handed the task of putting together a new cabinet consisting of non-partisan experts to Brigitte Bierlein - the then sitting President of the Constitutional Court. Justifying his decision, Alexander van der Bellen stressed that he was appointing Brigitte Bierlein as Chancellor in an 'extraordinary political situation requiring particular determination in serving the Republic', as the new government's task would be to build up public confidence in political institutions ${ }^{11}$. Sworn in on 3 June 2019, the Brigitte Bierlein government performed its duties until the new government was formed after the snap elections to the National Council.

9 Antrag der Abgeordneten August Wöginger, Dr. Pamela Rendi-Wagner, MSc, Herbert Kickl, Mag. Beate Meinl-Reisinger, MES, Kolleginnen und Kollegen betreffend ein Bundesgesetz, mit dem die XXVI. Gesetzgebungsperiode des Nationalrates vorzeitig beendet wird https:// www.parlament.gv.at/PAKT/VHG/XXVI/A/A_00850/fname_754767.pdf, retrieved 14 October 2019.

10 Parlamentskorrespondenz Nr. 589 vom 27.05.2019, Nationalrat entzieht der Regierung das Vertrauen, https://www.parlament.gv.at/PAKT/PR/JAHR_2019/PK0589/index.shtml, retrieved 14 October 2019.

11 Brigitte Bierlein wird Bundeskanzlerin, https://www.bundespraesident.at/aktuelles/detail/news/brigitte-bierlein-bundeskanzlerin, retrieved 14 October 2019. 
Social assessment of political crisis

The results of the poll carried out by the SORA/ISA Institute between 21-26 May 2019 indicates that the video sting scandal has deeply undermined the public's confidence in Austrian politics. Even 59\% of those polled admitted that the scandal had (more or less) had influence on their trust in political institutions, with $36 \%$ denying this. The poll shows that Austrians are disappointed with political parties - more than a half of the respondents (56\%) believe that they are only interested in votes and do not serve/care about the voters' interests, with only $40 \%$ disagreeing.

Table 1. Confidence in the political system and parties in Austria

\begin{tabular}{|l|l|l|l|l|}
\hline & $\begin{array}{l}\text { strongly } \\
\text { agree }\end{array}$ & $\begin{array}{l}\text { somewhat } \\
\text { agree }\end{array}$ & $\begin{array}{l}\text { somewhat } \\
\text { disagree }\end{array}$ & disagree \\
\hline $\begin{array}{l}\text { Publication of the Ibiza video undermined my } \\
\text { confidence in the political system in Austria }\end{array}$ & 33 & 26 & 19 & 17 \\
\hline $\begin{array}{l}\text { Parties only solicit votes and do not care about } \\
\text { voters' interests }\end{array}$ & 26 & 30 & 28 & 12 \\
\hline
\end{tabular}

Source: https://strategieanalysen.at/wp-content/uploads/2019/05/ISA-SORA-WahlanalyseEUWahl-2019.pdf, s. 12., retrieved 14 October 2019.

The result of the poll carried out by the INTEGRAL Institute in August and September 2019 shows that the assessment of democracy in Austria depends on the party's electorate ${ }^{12}$. The most satisfied with the state of democracy are ÖVP (75\%) and SPÖ (72\%) voters, while this view is only shared by $40 \%$ of FPÖ voters. More than a half of those polled (55\%) claim that democracy functions just as well or just as poorly as 10 years prior, but as many as $29 \%$ think that democracy in Austria used to be in a better state 10 years before. More than a third of respondents (35\%) assume a pessimistic outlook for the future, fearing a decline in democracy in Austria within the next decade. As many as four in ten of those polled by INTEGRAL see a threat to democracy in, among other issues, both right- and left-wing extremism, migrants and right-wing populists.

The collapse of the ruling coalition is an issue that has very much divided ÖVP- FPÖ voters. Although the majority find the end of the ÖVP-FPÖ coalition to be an adequate solution (38\%), 34\% are disappointed with the fall of the Sebastian Kurz cabinet. The ruling parties' voters feel particularly let down: The FPÖ

12 INTEGRAL-Studie 2019, https://www.integral.co.at/downloads/Pressetext/2019/09/ Pressetext_Tag_der_Demokratie_-_Sep.pdf retrieved 14 October 2019 
(67\%) and the Christian Democrats (59\%). In contrast, relief was expressed by those voting for the Greens (86\%), the SPÖ (72\%), and the NEOS $(65 \%)^{13}$.

On the National Council election day, 29 September 2019, the SORA/ISA Institute repeated its series of surveys on democracy and Ibiza-gate. Although the vast majority of those surveyed still see democracy as the best form of governance (63\%), compared to the results of a similar poll from 2017, one can observe a 9 percentage point slide (72\%) and an 18 percentage points drop since $2013(81 \%)^{14}$

The prevailing opinion on Ibiza-gate among all voters is that it is characteristic of individual politicians (35\%). Herein, $28 \%$ of respondents see the scandal as typical of the FPÖ, $17 \%$ of those polled think that this is a problem common for most parties, while only $15 \%$ generalise this view to all political parties. This has been a divisive issue across individual electorates. For both SPÖ's and Greens' voters, Ibiza-gate is characteristic of the far-right populist Freedom Party. However, the Christian Democratic electorate (54\%) and Freedom party electorate (56\%) claim that the fault lies rather in individual politicians and not the entire party. In addition, as many as $35 \%$ of FPÖ voters believe that the corruption scandal is characteristic of the majority of political parties. A similarly critical view of political parties in Austria is shared by those respondents who did not vote in the elections - as many as $28 \%$ think that the Ibiza video is characteristic of all parties, $21 \%$ hold that it is characteristic of the majority of them, while $32 \%$ believe that this problem is typical of individual politicians.

An interesting insight is provided by a survey on the uncovering of the scandal and the assessment of its consequences for the political system (Chart 2). Here, $46 \%$ of all voters find that media exposing the affair is very important for democracy, $29 \%$ somewhat agree with this statement and only $7 \%$ completely disagree. The ones that most appreciate the fact that the media exposed the affair for the good of democracy are Green voters (78\%), Social Democrats voters (69\%) and NEOS voters (56\%). This is strongly opposed by as many as $34 \%$ of FPÖ voters and another $33 \%$ somewhat disagree with this view, which confirms that the majority of Freedom party's voters believe that the Ibiza video was a political provocation and a conspiracy targeting that party.

${ }_{13}$ M. Zandonella, F. Perlot, Wahltagsbefragung und Wählerstromanalyse, Europawahl 2019,26. Mai 2019, s. 19. https://www.sora.at/fileadmin/downloads/wahlen/2019_EUW_Wahlanalyse.pdf retrieved 14 October 2019

14 SORA/ ISA Institut 2019, s. 10. https://www.sora.at/themen/wahlverhalten/wahlanalysen/nrw19.html, retrieved 14 October 2019 
Chart 1. Public opinion poll: Who is the 'Ibiza video' characteristic of?

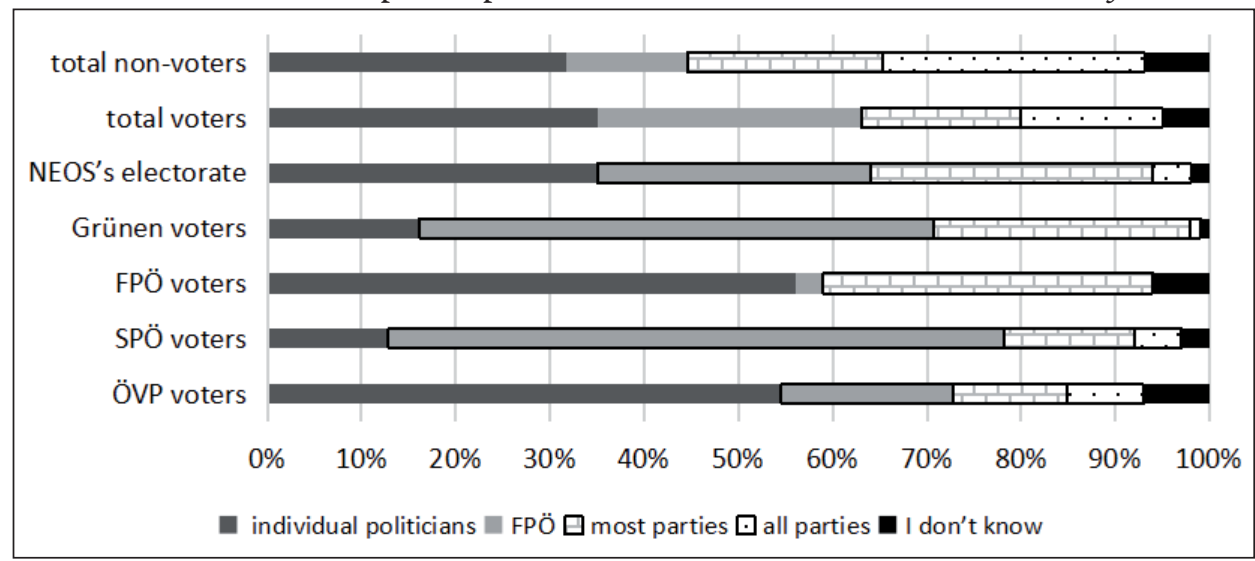

Source: M. Zandonella, F. Perlot, Wahltagsbefragung und Wählerstromanalyse. Nationalratswahl 2019, 29. September 2019, s. 17-18. https://www.sora.at/fileadmin/downloads/wahlen/2019_NRW_GrafikenWahltagsbefragung.pdf, retrieved 14 October 2019

Chart 2. Public opinion poll: Exposing an affair such as the Ibiza video by the media is important for democracy.

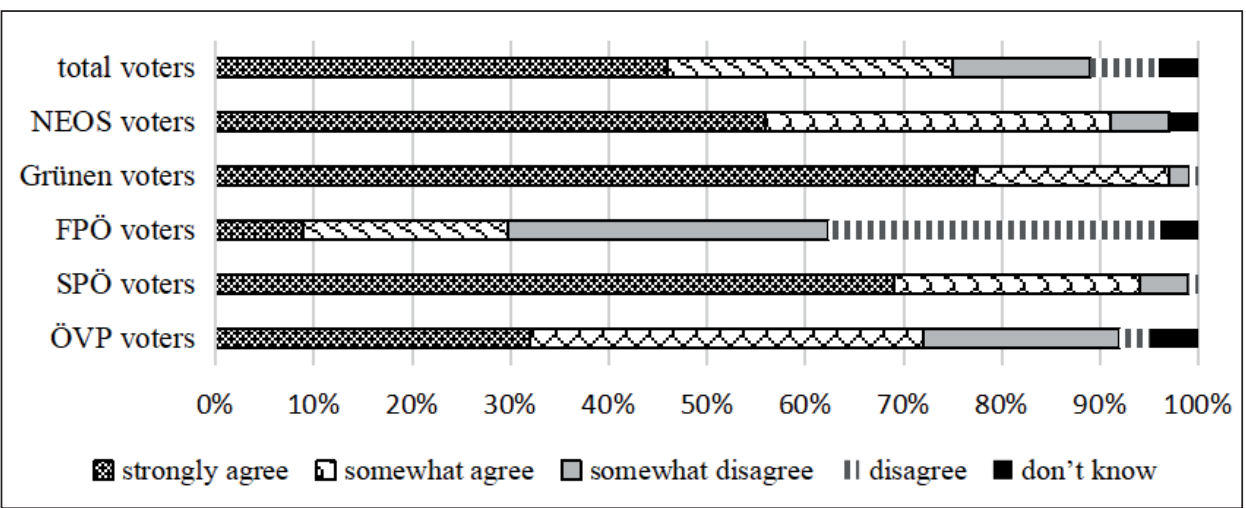

Source: M. Zandonella, F. Perlot, Wahltagsbefragung und Wählerstromanalyse. Nationalratswahl 2019, 29. September 2019, s. 41. https://www.sora.at/fileadmin/downloads/wahlen/2019_NRW_GrafikenWahltagsbefragung.pdf, retrieved 4 October 2019 
Analysis of the results of the 29 September 2019 National Council election

Election results (Table 2) demonstrate both the strong position of Sebastian Kurz's Christian Democrats and the weakness of their political rivals - not only of the extreme right compromised by the scandal, but also of the Social Democrats, who obtained the lowest result since the end of the Second World War. A low, by Austrian standards, voter turnout (75.6\%) proves that the citizens had become put off by politics. Five parties made it to the 26th National Council. After the 2019 election, the allocation of seats in the 183 member lower house is as follows: The ÖVP 71 seats, the SPÖ 40 seats, the FPÖ 31 seats, the Greens 26 seats and the NEOS 15 seats. Peter Pilz's Jetzt party, which held 8 seats between 2017 and 2019, but failed to clear the election threshold in 2019 by gaining only $1.9 \%$ support, did not make it to the 26th National Council.

Table 2. 29 September 2019 National Council election resul

\begin{tabular}{|l|l|l|l|l|}
\hline Party & $\begin{array}{l}\text { Number of votes } \\
\text { cast }\end{array}$ & $\begin{array}{l}\text { Percentage of votes } \\
\text { cast }\end{array}$ & $\begin{array}{l}\text { Percentage of loss/ } \\
\text { gain with respect } \\
\text { to previous 2017 } \\
\text { elections }\end{array}$ & $\begin{array}{l}\text { Number of seats in } \\
\text { the 26th National } \\
\text { Council (loss/gain } \\
\text { in comparison } \\
\text { to the previous } \\
\text { council) }\end{array}$ \\
\hline ÖVP & 1.789 .417 & $\mathbf{3 7 . 5}$ & $+\mathbf{6}$ & $\mathbf{7 1 ( + 9 )}$ \\
\hline SPÖ & 1.011 .868 & 21,2 & $\mathbf{- 5 . 6 6}$ & $\mathbf{4 0}(\mathbf{- 1 2})$ \\
\hline FPÖ & 772.666 & 16.2 & $\mathbf{- 9 . 7 7}$ & $\mathbf{3 1}(\mathbf{- 2 0})$ \\
\hline GRÜNE & 664.055 & $\mathbf{1 3 . 9}$ & $+\mathbf{1 0 . 1}$ & $\mathbf{2 6}(+\mathbf{2 6})$ \\
\hline NEOS & 387.124 & 8,1 & +2.8 & $\mathbf{1 5}(+5)$ \\
\hline PILZ & 89.169 & 1,9 & $\mathbf{- 2 . 5}$ & $\mathbf{0}(-\mathbf{8})$ \\
\hline $\begin{array}{l}\text { Other } \\
\text { parties }\end{array}$ & 62.947 & & & \\
\hline
\end{tabular}

Source: Bundesministerium Inneres, Österreich, vorläufiges Endergebnis inklusive Wahlkarten-gesamt, https://wahl19.bmi.gv.at retrieved 14 October 2019

The Austrian People's Party came in a clear first receiving the most votes (37.5\%). Moreover, the 6 percentage point increase compared to the previous elections put the Christian Democrats in the lead. Still, analysis of the previous three parliamentary elections (2013, 2017, and 2019) shows increasing support for ÖVP (see chart 3). Since 2013, the Christian Democrats have increased their share of the vote by 13.5 percentage points. No other party has managed to achieve such a result in the last 6 years. In the same time, the SPÖ has lost 5.6 percentage points. In 2018, for the first time in its history, the SPÖ chose 
a female leader - Pamela Rendi Wagner, yet neither the party's political makeover nor a smear campaign against Kurz and the FPÖ did guarantee success for the Social Democrats. The Social Democrats gained only $21.2 \%$ of the votes, the worst national election result for the party in its history.

The last elections saw the defeat of the FPÖ, which, compared to 2017 results, registered a loss of support by 9.7 percentage points. In the election, the Freedom Party of Austria gained only 16.2\% support. The best election result since 1986 was registered by the Greens (13.9\%), who in previous elections did not manage to clear the $4 \%$ electoral threshold and thus obtained no seats in the parliament. The impressive comeback of the Greens and taking 26 seats in the National Council is a result of enacting a good electoral campaign and having a manifesto oriented towards climate and environmental change issues. Liberals from the NEOS (The New Austria and Liberal Forum), present in the parliament since 2013, also have been gradually strengthening their position on the Austrian political scene. The last elections brought $8.1 \%$ support to the NEOS party, i.e. a 2.8 percentage point increase.

Chart 3. Support gained by political parties in 2013-2019 National Council

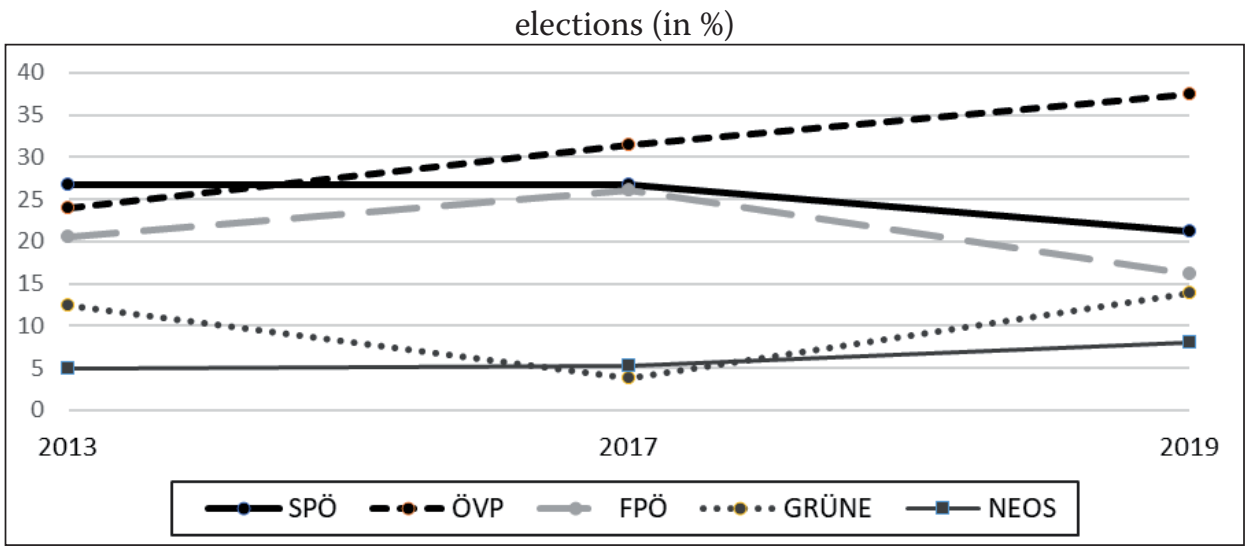

Source: Own data based on information from the website: https://bmi.gv.at/412/Nationalratswahlen/, retrieved 14 October 2019

The shift of voters (Table 3) observed in the recent National Council elections indicates that the ÖVP held as much as $86 \%$ of its 2017 voters, additionally taking over some form the FPÖ (20\% of 2017 voters) and SPÖ (5\%) electorate. Furthermore, the Christian Democrats lost some votes to NEOS (5\%), as well as to the Greens (3\%) and non-voters (3\%). The Social Democrats, who mobilised $68 \%$ of their 2017 voters, lost even as much as $14 \%$ of their electorate, who in 
turn voted for the Greens or did not take part in the elections at all (6\%). Furthermore, the FPÖ held only $54 \%$ of its past electorate, recording the largest losses to the ÖVP (258,000 votes). Indeed, almost two out of ten persons who voted for the FPÖ two years prior stayed at home during the last National Council election (235,000 non-voters). Of note, the Greens took most of the SPÖ electorate (193,000 votes), which is $14 \%$ of the Social Democrats' voters from 2017. As much as $34 \%$ of NEOS 2017 voters and $40 \%$ of the Jetzt party's voters chose to vote for the Greens in 2019.

Table 3. Voter shift in the 2019 National Council election (in \%

\begin{tabular}{|c|c|c|c|c|c|c|c|c|c|c|}
\hline & \multicolumn{9}{|c|}{2019} \\
\hline & & ÖVP & SPÖ & FPÖ & Grüne & NEOS & Jetzt & $\begin{array}{l}\text { Other } \\
\text { parties }\end{array}$ & $\begin{array}{l}\text { Non- } \\
\text { voters }\end{array}$ & Total \\
\hline \multirow{8}{*}{ 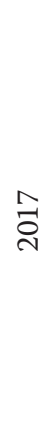 } & ÖVP & 86 & 1 & 1 & 3 & 5 & 0 & 0 & 3 & $100 \%$ \\
\hline & SPÖ & 5 & 68 & 2 & 14 & 3 & 1 & 0 & 6 & $100 \%$ \\
\hline & FPÖ & 20 & 3 & 54 & 2 & 2 & 0 & 1 & 18 & $100 \%$ \\
\hline & Grüne & 1 & 0 & 2 & 80 & 10 & 1 & 1 & 5 & $100 \%$ \\
\hline & NEOS & 2 & 0 & 1 & 34 & 55 & 1 & 1 & 7 & $100 \%$ \\
\hline & Jetzt & 3 & 1 & 1 & 40 & 13 & 26 & 1 & 13 & $100 \%$ \\
\hline & $\begin{array}{l}\text { Other } \\
\text { parties }\end{array}$ & 17 & 9 & 2 & 20 & 12 & 4 & 24 & 13 & $100 \%$ \\
\hline & Non-voters & 2 & 3 & 1 & 2 & 1 & 1 & 1 & 89 & $100 \%$ \\
\hline
\end{tabular}

Source: M. Zandonella, F. Perlot, Wahltagsbefragung und Wählerstromanalyse. Nationalratswahl 2019, 29. September 2019, s. 5. https://www.sora.at/fileadmin/downloads/wahlen/2019_NRW_ Grafiken-Wahltagsbefragung.pdf, retrieved 14 October 2019

\section{Conclusion}

The consequence of the scandal at the pinnacles of power in Austria has been a drop in voter confidence in political parties and institutions, which is reflected in the voters being discouraged from politics and participating in elections. Voter turnout in the recent National Council elections (75.6\%) is one of the lowest in the post-war history of Austria. The video sting affair has shown not only what goes on behind the scenes of the all-or-nothing fight for power and the role the media plays in influencing public opinion, but also how ready populist politicians are to get into bed with Russian oligarchs. Polarisation in Austrian society between the left and right wing of politics is becoming entrenched, thus determining a more or less optimistic view of the future of Austrian democracy and threats to its political system. 
The snap National Council election brought defeat to the Freedom Party. Two days after the results had been announced, Heinz Christian Strache, in an emotional statement, withdrew from politics and suspended his FPÖ membership. According to some commentators, Strache's resignation supposedly neutralised the criticism that befell the former chairman of the Freedom Party and, at the same time, sank the entire party. Yet, it was not only Ibiza-gate but another scandal, revealed in September 2019, connected to party spending (German: Spesenaffäre) that implicated the former FPÖ chairman Strache in the embezzlement of party funds. Looking at the mass exodus of FPÖ voters during the National Council election, one may suspect that the charges of misappropriation of party funds by its leader caused the most damage to the FPÖ, discouraging even its traditional electorate from voting for that party. Immediately after the elections, the new FPÖ chairman Norbert Hofer announced that the party was in pressing need of an organisational overhaul to restore voter confidence.

The National Council elections of 29 September 2019 were a clear victory for the Christian Democrats - Sebastian Kurz's win is his personal success. The ÖVP owes the good election result to a predominantly favourable opinion of Kurz's cabinet, social and tax system reforms, and its attempts to counter illegal immigration and religious extremism. The 2017-2019 government alliance between the Christian Democrats and the Freedom Party ended with the ÖVP taking over as much as $20 \%$ of the disgruntled FPÖ voters (from 2017). A very much weakened Freedom Party of Austria returned after the 2019 election to its role of the parliamentary opposition, no longer a threat for Christian Democrats in their fight for votes.

The Christian Democrats did not lose the support of its electorate despite harsh criticism from the Social Democrats and the Greens, who accused the ÖVP of being co-responsible for the government crisis brought about by inviting right -wing populists to govern. During the campaign, Kurz emphasised many times that calling early elections was not his choice, but a political necessity. Despite the difficulties and differences between the coalition partners, Kurz's evaluation of the ÖVP-FPÖ government's 18-month rule was positive and he declared that the ambitious reform programme it had initiated would be continued if he were elected chancellor again.

The electoral success of the Austrian People's Party does not guarantee it will get to rule alone. The ÖVP must find a coalition partner to form a federal government with for the next five years. Sebastian Kurz cannot afford another snap election. The Social Democrats have already reproached him for allowing his decisions to cause the government to fall twice: once in 2017, when the great 
coalition collapsed, and in May 2019, when Ibiza-gate was revealed. Austrians thus expect a stable government, resistant to both internal strife, as well as to political affairs and scandals.

\section{Bibliography}

\section{Sources}

- Antrag der Abgeordneten August Wöginger, Dr. Pamela Rendi-Wagner, MSc, Herbert Kickl, Mag. Beate Meinl-Reisinger, MES, Kolleginnen und Kollegen betreffend ein Bundesgesetz, mit dem die XXVI. Gesetzgebungsperiode des Nationalrates vorzeitig beendet wird https://www.parlament.gv.at/PAKT/VHG/XXVI/A/A_00850/fname_754767. pdf , retrieved 14 October 2019.

- Bundesministerium Inneres. Österreich, Endergebnis inklusive Wahlkarten-gesamt, 2019 https://wahl19.bmi.gv.at/, retrieved 14 October 2019.

- Bundesrecht konsolidiert: Gesamte Rechtsvorschrift für Bundes-Verfassungsgesetz, https://www.ris.bka.gv.at/GeltendeFassung.wxe?Abfrage=Bundesnormen\&Gesetze snummer $=10000138$, retrieved 14 October 2019.

- Debatte über die Dringliche Anfrage in der 78. Sitzung des Nationalrates, XXVI. GP, am 27. Mai 2019. https://www.parlament.gv.at/PAKT/VHG/XXVI/UEA/UEA_00237/ imfname_754666.pdf, retrieved 14 October 2019.

- Dringliche Anfrage gem. $\mathbb{S} 93$ Abs. 2 GOG der Abgeordneten Mag. Jörg Leichtfried, an den Bundeskanzler betreffend Scheitern der Bundesregierung Kurz, Eingelangt am 27.05.2019, https://www.parlament.gv.at/PAKT/VHG/XXVI/J/J_03619/ fname_754320.pdf, retrieved 14 October 2019.

- Ergebnisse der Europawahl Österrreichs 2019, https://europawahlergebnis.eu/nationale-ergebnisse/osterreich/2019-2024/, retrieved 14 October 2019.

- INTEGRAL-Studie 2019, https://www.integral.co.at/downloads/Pressetext/2019/09/ Pressetext_Tag_der_Demokratie_-_Sep.pdf retrieved 14 October 2019.

- Parlamentskorrespondenz 588 vom 27.05.2019, Nationalrat spricht gesamter Bundesregierung das Misstrauen aus, https:/www.parlament.gv.at/PAKT/AKT/SCHLTHEM/ SCHLAG/J2019/110Misstrauensantrag.shtml, retrieved 14 October 2019.

- Parlamentskorrespondenz 589 vom 27.05.2019, Nationalrat entzieht der Regierung das Vertrauen, https://www.parlament.gv.at/PAKT/PR/JAHR_2019/PK0589/index. shtml, retrieved 4 October 2019.

- SORA/ISA Institut für Strategieanalyse, Wahl zum Europäischen Parlament 2019 in Österreich Wahlanalyse, 2019, https://strategieanalysen.at/wp-content/uploads/2019/05/ ISA-SORA-Wahlanalyse-EUWahl-2019.pdf, retrieved 14 October 2019.

- SORA/ISA Institut für Strategieanalyse, Wahlanalyse Nationalratswahl 2019, 2019, https://www.sora.at/fileadmin/downloads/wahlen/2019_NRW_Wahlanalyse.pdf, retrieved 14 October 2019.

- Zandonella M., F. Perlot, Wahltagsbefragung und Wählerstromanalyse, Europawahl 2019, 2019, https://www.sora.at/fileadmin/downloads/wahlen/2019_EUW_Wahlanalyse.pdf, retrieved 14 October 2019. 
- Zandonella M., F. Perlot, Wahltagsbefragung und Wählerstromanalyse. Nationalratswahl 2019, 2019, https://www.sora.at/fileadmin/downloads/wahlen/2019_NRW_Grafiken-Wahltagsbefragung.pdf, retrieved 14 October 2019.

\title{
Literature:
}

- Hajek P., Die Analyse zur Europa-Wahl 2019: Wer wen warum wählte, https:// politikmagazin.at/europa-wahl-2019-wer-wen-warum-waehlte/?cookie-statechange $=1572255209253$, retrieved 14 October 2019

- Klepka R., Parlament w państwie federalnym na przykładzie Austrii, Belgii, Niemiec i Szwajcarii. Analiza porównawcza, Wydawnictwa Sejmowe. Warszawa 2013.

- Miecznikowska J., Zmiany na scenie politycznej Austrii-analiza wyników przedterminowych wyborów do Rady Narodowej w 2017r, „Studia Politica Germanica” 2017, nr 1 (6).

- Sarnecki P., System konstytucyjny Austrii, Wydawnictwo Sejmowe, Warszawa 1999.

- Sarnecki P., Republika Federalna Austrii, [w:] Opozycja parlamentarna, E. Zwierzchowski (red.), Wydawnictwa Sejmowe. Warszawa 2000.

\begin{abstract}
This article examines the political consequences of the biggest government crisis in the history of the Second Republic of Austria. This ensued after the media revealed in May 2019, the corruption in the activity of the Freedom Party of Austria. The video sting scandal, dubbed Ibiza-gate, has shaken Austria, prompted the collapse of the coalition between the Austrian People's Party and Freedom Party of Austria, and subsequently brought down the government after the National Council had voted no-confidence to Sebastian Kurz's cabinet. In this article, a hypothesis is put forward that the scandal has strengthened the Christian Democrats' position on the Austrian political scene, despite opposition criticism that ÖVP, which decided to cooperate with the extreme right, is co-responsible for the political crisis.
\end{abstract}

Keywords: Austria, Sebastian Kurz, political crisis, vote of no-confidence, National Council election, Freedom Party of Austria

Kryzys rządowy w Austrii w 2019 roku - polityczne konsekwencje afery taśmowej

Streszczenie: W artykule ukazano polityczne konsekwencje największego w historii II Republiki Austrii kryzysu rządowego, który był następstwem ujawnienia w maju 2019r. przez media korupcyjnych propozycji składanych przez polityków Wolnościowej Partii Austrii. Afera taśmowa nazywana „Ibiza-gate” wstrząsnęła Austrią, doprowadziła do rozpadu koalicji Austriackiej Partii Ludowej i Wolnościowej Partii Austrii, a następnie do upadku rządu Sebastiana Kurza w wyniku wyrażenia przez Radę Narodową wotum nieufności. W artykule przyjęto hipotezę, że skandal umocnił pozycję chadecji na austriackiej scenie politycznej i to mimo krytyki ze strony partii opozycyjnych, że ÖVP która podjęła się współpracy ze skrajną prawicą, jest współodpowiedzialna za kryzys polityczny.

Słowa kluczowe: Austria, Sebastian Kurz, kryzys polityczny, wotum nieufności, wybory do Rady Narodowej, Wolnościowa Partia Austrii 